\title{
RAIMONDA SIMANAITIENÉ
}

Vytauto Didžiojo universitetas, Lietuva

Vytautas Magnus University, Lithuania

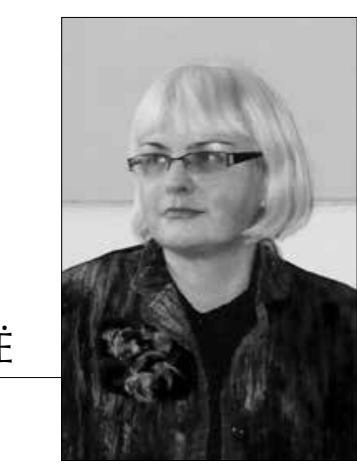

\section{INDRĖS STULGAITĖS-KRIUKIENĖS KÜRYBA: NUO ESTETIZUOTOS STIKLO SKULPTÜROS IKI KONCEPTUALIOS INSTALIACIJOS}

\author{
Creation of Indrè Stulgaitè Kriukienè: \\ From Aestheticized Glass Sculpture to Conceptual Installations
}

\begin{abstract}
SUMMARY
Glass artist Indre Stulgaite Kriukienè is known as a participant of numerous exhibitions in Lithuania and abroad. The artist mainly creates exhibition works from which the most notable are a series of sculptures and conceptual compositions (installations, ready-made, video projects). The works probe the problematics of human existence, the preservation of civilization, the importance of home. However, to capture these classic themes, the artist uses a personal outlook, original aspects, associations and symbols, while questioning the ordinary purpose of objects and conducting art research. A special knowledge of materials and techniques facilitates the shaping of intriguing art-work forms, which create highly suggestive and aesthetic plasticity in the author's creation.
\end{abstract}

\section{SANTRAUKA}

Stiklo dailininkė Indrẻ Stulgaitė-Kriukienè yra žinoma kaip daugelio parodų Lietuvoje ir užsienyje dalyvè. Menininkẻ kuria ne tik stiklo dizainą, bet ir parodinius darbus, iš kurių išsiskiria konceptualūs kūriniai (instaliacijos, ready made, video projektai) ir skulptūrų serijos. Juose plètojama žmogaus egzistencijos, civilizacijos išsaugojimo, būties, namų svarbos tematika. Šioms klasikinėms, mene gana dažnai pasitaikančioms temoms ịprasminti pasitelkiamas asmeninis požiūris, pasirenkami originalūs aspektai, asociacijų ir simbolių kalba, vykdomi meno tyrimai, kvestionuojamos ịprastos daiktu paskirtys. Intriguojančioms I. Stulgaitės-Kriukienès kūrinių formoms skleistis padeda ypatingas medžiagiškumo ir technikų išmanymas, padedantis išryškinti autorės stiklo darbų plastikos įtaigumą ir estetiką. 


\section{IVADAS}

Indrė Stulgaitè-Kriukienė Vilniaus dailès akademijos Kauno fakultete stiklo specialybę pradejo studijuoti $2001 \mathrm{~m}$. Mokytis dailès ją paskatino Kauno A. Martinaičio dailès mokyklos mokytojas ekspertas Andrius Valius. Vakarinèse klasėse, kurias lankė Indrè, jis dèstè piešimą ir ižvelgè merginos gabumus. Stiklo specialybę būsima menininkè rinkosi kaip universalia, jos nuomone, apimančią piešimo, tapybos, skulptūros raiškos principus $^{1}$. Bet pradejjusi gilintis ì šią Lietuvoje mažai išplètotą sritị, jau bakalauro studijų metu Stulgaitė-Kriukienè suvokè, kokia ypatinga stiklo medžiaga, ir itin susidomèjo stiklo technologijomis. Dailininke aiškiai suprato, kad pasirinkta specialybė glaudžiai siejasi su amato igūdžiais, galinčiais neabejotinai sustiprinti ar net nulemti kūriniu iš šios medžiagos estetika, itaigiau atskleisti naratyvines ir plastines darbu prasmes. Išbandžiusi i̇vairias stiklo technologijas, kūrèja labiausiai susižavejjo karšto stiklo formavimu, kurio pažinimui buvo sudarytos galimybès VDA KF mokomosiose stiklo dirbtuvėse. Tad baigiamajame Stulgaitės-Kriukienès bakalauro studiju darbe "Stand'Art" (2005) išryškëjo ypatingas jaunosios dailininkès gebejjimas pasinaudoti karšto stiklo liejimo techni- ka ir skulptūriškai atvaizduoti žmogaus figūrą stiklo formos viduje².

Studijuodama Indre turëjo ne vieną mokytoją. Mokantis neabejotinai padejjo dėstytoju Vytauto Janulionio, Valmanto Gutausko, Arūno Daugèlos patarimai, tačiau autoritetu dailininkè ieškojo ne tik Lietuvoje. Jos didžiausiu kūrybos ịkvèpèju jau magistrantūros metu (20052007) tapo švedu dailininkas, žinomas karšto stiklo liejimo technologiju specialistas Bertilas Vallienas (g. 1938), suteikęs ypatingą impulsą Indrès skulptūrinei plastikai ${ }^{3}$.

Stulgaitè-Kriukienė nuo pat studiju pradžios drąsiai žengè sudètingu ir nelengvu meninio stiklo kūrèjo keliu: sukurdavo unikalius darbus, dalyvaudavo parodose ir ivairiuose tarptautiniuose projektuose. Atsakingas dailininkès požiūris i savo specialybę skleidžiasi iki šių dienu, kai ji yra tapusi viena įdomiausiu stiklo menininkių Lietuvoje ${ }^{4}$. Tad šiame straipsnyje užsibrèžta nuosekliai išnagrinèti Stulgaitès-Kriukienès kūryba, išsamiai aptarti jos darbų tematika, specifiką ir plastinius bruožus. Menininkès raiška tyrinëjama taikant chronologini ir tipologini metodus, atliekant naratyvinę, formaliąją bei stilistinę jos kūrinių analizę, imant interviu iš pačios dailininkès.

\section{DAILININKĖS ANKSTYVOSIOS KŪRYBOS TEMATIKA IR PLASTINĖ RAIŠKA}

$X X$ a. pabaigoje-XXI a. pirmame dešimtmetyje viena dominuojančiu stiklo meno tendenciju Lietuvoje buvo skulptūrinè stiklo plastikos kryptis (Simanai- tienè 2018: 117). Vis dèlto tuo metu kylanti jaunesnè dailininku karta jau žvalgèsi naujų idejju, sėmèsi ju iš stiklininkystejje pirmaujančių Skandinavijos ša- 
lių, Estijos, Čekijos ir kitų mokyklų. Šios patirtys labiausiai siejosi su plastinès raiškos modernèjimu, kintančiu požiūriu i stiklo meną ir kitas taikomosios dailès šakas. Taigi kai kurių Lietuvos stiklo kūrëjų darbuose pamažu pradejjo rastis konceptualumo požymių. Čia būtų galima paminèti tokias autores kaip Irina Peleckienè, Julija Pociūtè, Valda Verikaitè, Audronè Andrulevičienè, ìvardinti ju meninius siekius ir eksperimentus. Pastarajai kartai priskirtina ir StulgaitèsKriukienės kūryba. Jos pirmieji postmodernistinio pobūdžio darbai turëjo žaismingumo, imitacijos, ansambliškumo, ready made formato požymių, implikavo stiklo ir kitų medžiagų dermes. Vienas tokių Stulgaitès-Kriukienès kūrybos pavyzdžių galètų būti stiklo objektų grupè „Špūlès" (2005) - čia pavaizduota grupè stiklinių siūlų ričių. Ši kūrinį derètų priskirti įdomiems medžiaginiams eksperimentams, susijusiems su tam tikrų plastinių sprendimų ieškojimu, kai viena medžiaga imituoja kita, tarkime, stiklas tekstilę (siūlus), oda - keramiką ir pan. Šitaip žaidžiama nauja estetika, leidžiančia suabejoti medžiaginėmis ypatybėmis (Šatavičiūtè-Natalevičienè 2018: 34). „Špūlių“ kompozicijoje pademonstruotas ir meistriškas karšto stiklo įvaldymas, darbas atrodo žaismingai, intriguojamai.

Vis dèlto ankstyvuoju kūrybos tarpsniu menininkė daugiausia pasirinkdavo skulptūrinį stiklo darbų formatą, o naratyviniu požiūriu labiausiai domèjosi egzistencine problematika, plètojo civilizacijos nykimo, ekologinès griūties, žmogaus vienišumo, niveliavimosi siužetus („Stand'art", „Skausmas“, "Ilgesys", "Ǐšalęs", "Žemètvarka").
Šios gilios, pamatinės temos išraiškingiausiai atsiskleidè kompozicijoje "Civilizacija“ (2007), kur išlieto stiklo pagrinde tarsi klimpo ịvairūs "svetimkūniai“: žemès teršalai, civilizacijos liekanos, žmonijos paliktos šiukšlès. Panaši kūrybinè pozicija atsispindejjo ir kūrinyje „(Ne)žinomasis" (2007)5. Šiame darbe taip pat analizuojami žmogaus būties, išlikimo klausimai. Kūrini sudarè keli plokštumoje išdèstyti lieto stiklo elementai, kuriuose ryškejjo „inkliuzai“ - dūlantys žmogaus palaikai. Egzistencinès temos menininkei išliko svarbios tiek besimokant magistrantūroje, tiek ir toliau, kai stiklininkè jau studijavo VDA aspirantūroje. Visiems šiems gelminès tematikos kūriniams ir juose vyraujančioms idejjoms perteikti buvo pasitelktos sudètingos studijinio stiklo apdirbimo technikos bei meninès raiškos priemonès (European Glass Context 2008: 190).

2009 m. persikèlusi gyventi iš Kauno i Panevėži ir pradejjusi dirbti dizainere savo vyro, žymaus stiklo menininko Remigijaus Kriuko, dirbtuvèje Indrè dar labiau susidomėjo XX a. antroje pusèje issibègèjusiu studijinio stiklo judèjimu, kuris apskritai yra vienas aktyviausiai analizuojamų reiškinių nūdienos stiklininkystès istorijoje $\mathrm{e}^{6}$. Studijinio stiklo judèjimo pamatinè pozicija yra ta, jog darbas individualioje studijoje, o ne fabrike, yra stiklo dailininko išlaisvejjimo nuo funkcionalių objektų kūrimo ir kelio i unikalų menini rezultatą garantas ${ }^{7}$. Tad Indrès gilinimasis ì studijini stiklą tapo itin dèsningas: menininkè pateko ì tokią veiklos aplinka, kuri jai natūraliai kèlè klausimus apie dailininko, dirbančio stiklo studijoje, sąlygas, kūrybos pobūdi, 
meistriškuma, funkcionalaus ir konceptualaus meno santykį. Dailininkè ir toliau siekẻ kurti skulptūrinę ir autorinę modernią plastika, gilinosi i karšto stiklo liejimo technologijas, kurias valdè jau beveik tobulai. Buvo sukurta daug nepaprastai estetiškų, grakščios, lenktos formos stiklo darbų, žavinčių tiek savo "lengva“" plastika, tiek ir stiklo skaidrumu, optika („,Sutemų laivas“, 2011; ,Saulèlydžio laivas“, 2012). "Stiklas Indrès darbuose visada kèlè daugybę asociacijų: skaidrus, optinis - giedrų jausmų išraišką (serija "Laivai“), šiurkštus, prigesęs, faktūriškas - nykstančios, žūstančios materijos nuojautą („Civilizacija“)" (Kogelytė-Simanaitienè 2008: 68).

Šiuo laikotarpiu buvo sukurta ir grupé skulptūrų namų tema. $\breve{i}$, kelerius metus plètota tema atskleidè autorès pomėgi gvildenti, nuosekliai analizuoti pasirinktą idejac parodų ekspozicijose ją perteikti originaliai ir vis kitaip bei tokiu būdu išvengti vizualios monotonijos, atspindèti ịvairiausias menininkès nuotaikas (Kogelytè-Simanaitienè 2014: 100). Stulgaitès-Kriukienès seriją (pradètą kurti 2010 m. ir varijuota pavadinimais „Namų dvasia“ ar „Ten, kur namai“) sudarè daugybè nedidelio dydžio skaidraus stiklo namelių. Kiekvieno ju išorè buvo panaši, bet vidinè plastinè išraiška skyrèsi stiklo žaižaravimu, spalva, optika, tekstūra. Menininkę žavèjo namelio simbolis, motyvo jaukumas, geometrinès formos paprastumas, stiklo monolito svoris, medžiagos kokybe ir grožis. Namų tema sukurti ir pavieniai darbai, kur stiklas igavo originalią kolorito traktuotę ar estetišką derini su kitomis medžiagomis - akmeniu, metalu („Vienišius“, 2011; „Mažojo princo pla- neta“, 2018). Autorès teigimu: „namai nèra tik eksterjerai ar interjerai, tai - ištisi žmogaus gyvenimai, būsenos, emocijos, išskirtiniai ar kasdieniniai gyvenimo tarpsniai. Tai - žmonijos visuma, žiburèliai languose keliaujant didmiesčiu ir kaimo vietovių keliais..." (Simanaitienè 2018: 144).

XXI a. antrajame dešimtmetyje Stulgaitès-Kriukienès kūryba vis labiau plètojosi meninès intrigos keliu. Prisimenant autorès pomėgi gvildenti pasirinktą tema, buvo sukurta keletas instaliacijų ir ready made'u, demonstruojančių išlietus ir žemèje ispaustus įvairaus dydžio stiklo pėdsakus („Jis“, 2009; "Kelyje“, 2012). Kūrinyje "Jis“ stiklinės pėdos buvo išdėstytos ant žemès, o „Kelyje“ jos jau „keliavo“ žemiuc pripildytame sename lagamine. Skulptūrinèje grupejje pavaizduotus išdidintus „Kaštonus“ (2013) autorè paskyrè šių pažeistų, sergančių medžiu problemai. Beje, šis darbas ypač efektingai atskleide faktūrinio matinio ir blizgaus stiklo dermę. Ne mažiau intriguojančiame, taip pat 2013 m. sukurtame objekte „Kilkès“ buvo panaudota grafinè spauda, sukèlusi ypatingo keistumo isspūdį: skaidrioje stiklinèje "skardinëje“ patalpintas realistinis žuvyčių motyvas dèl optinių stiklo savybių keitèsi pagal žiūrèjimo kampą - buvęs plokščias, skardinę pakreipus, „žuvytėmis“ užpildydavo visą tūrį... Galiausiai dar vienas darbas, eksponuotas „smèlio dèžèje“. Čia skaidraus ir spalvoto stiklo kontrastais žaižaravo užsilikę, regis, ką tik žaidusių vaikų „Žaislai“" (2015) (Stulgaitè-Kriukienė 2020: 87). Dalis šių kūrinių pasižymèjo mįslingumu, šmaikštumu, ironija, balansavo tarp stiklo skulptūros, objekto, instaliacijos. 


\section{MENININKĖS BRANDŽIOSIOS KÜRYBOS POKYČIAI KONCEPTUALAUS MENO LINKME}

Taigi pamažu vis reikšmingesnè stiklininkès kūryboje darèsi konceptuali raiška. Nuo $2015 \mathrm{~m}$. dailininke pradèjo studijuoti VDA meno doktorantūroje. Šios studijos tapo ypatingu akstinu tobulèti, keistis, patirti plastinę kaita, atlikti meninius tyrimus. Tad $2016 \mathrm{~m}$. buvo sukurti keli instaliacinio pobūdžio darbai, sutelkę ne tik stiklo medžiagą ar technologijas, bet ir kitas šiuolaikines medijas. Pirmiausia sukurta interaktyvi, ekologijos problematiką gvildenanti Stulgaitės-Kriukienès kompozicija „Atmintis“ (2016), kuria, pasitelkus medžio kamieną, stiklo vamzdelius, raudoną skysti, garsa, buvo siekiama imituoti nukirsto medžio kraujagyslių pulsavimą.

Toliau kūrybinių sumanymų ir eksperimentu objektu buvo pasirinkta taurè. Autore atkreipé dèmesị i $i$ ši objektą kaip i tipišką utilitaru stiklo dirbinį, manydama, kad būtent jis gali padèti atsakyti i nuolatos menininkę jaudinusị klausimą: ar i̇manoma funkcionalų daiktą (šiuo atveju taurę) "paversti“ konceptualiu meno kūriniu? İ ši klausimą bandyta atsakyti sukuriant net keletą instaliaciju, video projektų ir apklausiant parodų žiūrovus.

Vienas pirmuju šios temos pagrindu sukurtų pavyzdžių buvo instaliacija „Brizas" (2016). Darbui buvo pasitelkti bambukiniai, fengšui tradicijoje naudojami vejjo varpeliai. Remiantis šiuo analogu, kūriniui panaudotos stiklo taurès, judesys ir garsas ${ }^{8}$. Serijinès, fabrikinės gamybos taurès čia buvo sukabintos kojelemis i viršu. Viso jų panaudota gerokai daugiau kaip šimtas vienetur. Kompozicija, eksponuota specifiškai apšviestoje, aptemdytoje erdveje, papildyta vejo pūti$\mathrm{mu}$, skatinančiu judeti taures. Atejusi žiūrovą lydėdavo ir skambančių taurių garso takelis, issijungiantis lankytojui užejjus i instaliacijos patalpa, o ir pačios siūbuojančios taurès kartkartėmis skambtelėdavo natūraliai susiliesdamos. Ši surežisuota aplinka žiūrovą veikè itin intriguojančiai, asociatyviai. Savitą kūrinio „Brizas“ poveiki recenzijoje aprašè menotyrininkẻ G. Aksamitauskaitė: „,... stebẻdama tauriu šešèlius ant žemès pamačiau, rodos, tokiu pat amorfiškų ir jokios apčiuopiamos fizinès formos šiuo atveju neturinčių ląstelių dauginimąsi: centre profazè, kai branduolys dar koncentruotas ir aiškus, šešèliams tolstant išryškèja chromosomos ir sunyksta aiškios membranos, toliausiai nuo šviesos šaltinio esančių taurių, i kurias spinduliai krenta smailesniu kampu, projekcijose ant žemès šviesos branduolys jau skilęs ir iš jo formuojasi branduolèliai. Viskas nuolat juda, skamba ir prieš lankytojo akis tai gimsta, tai vèl i pirmini būvi grižta biologiniais principais besiremianti, bet kartu ir visai nefizinè medžiaga!" (Aksamitauskaitè 2017: 25)

$2016 \mathrm{~m}$. dailininkei buvo itin produktyvūs. Tuo laiku sukurtas dar vienas konceptualaus pobūdžio darbas, demonstruotas keliose parodose Lietuvoje (Vilniuje) bei Švedijoje. Tai video projektas "Ritualai“. Autorè siekè, jog čia vèl būtu pasitelkta tauré, kvestionuojanti nusistovejusius "gèrimo" kultūros bei funkcinio naudojimo principus. Kūrinys buvo demonstruojamas video būdu, ekrane vienu metu rodant penkiolika kadru su gèrimo pylimo i taurę veiksmu. „Egzistuoja pylimo i taurę etiketas, tam skiriamos įvairių formų taurès, vartojami skirtingų temperatūru gèrimai (vynai, 
kokteiliai ar konjakas). Pylimo veiksmas visiems aiškus ir suprantamas. Šio projekto atveju taurès funkcija "ipilti i“ lieka, tačiau domimasi tuo, kas nutinka, kuomet i ją pilamas skystis yra $1200^{\circ} \mathrm{C}$ temperatūros stiklas? Taurès funkcija sunaikinama, tolimesnis ritualas kinta gerti iš jos jau tampa nę̇manoma", - aiškindama šio kūrinio sumanymą teigè menininkė (Stulgaitè-Kriukienė 2020: 90). Akivaizdu, kad i taurę buvo pilamas ne vynas, o karštas stiklas, suniokodavęs taurę ir sukeliantis užburiantį ir keistą vyksma, verčiantį indą pulsuoti, glebti, rangytis. Taip buvo išryškintos ir stiklo materijos "gyvybinès" galios.

Taurę, kaip tiriamaji objekta, Stulgaitè-Kriukienè dar kartą panaudojo atlikdama ilgalaikị, maždaug metus trukusi tyrimą su kūrinio vertintojais. $2017 \mathrm{~m}$. menininke savo pažistamiems menotyrininkams, dailininkams, meno studentams ir kitiems respondentams išsiuntinejo nuotrauką su nufotografuota gulinčia pramoninès gamybos taure, kiek dirbtinai sulenkta kojele. I indą buvo ipilta keisto mèlyno „skysčio“ (silikono), kuris iš dalies ištekejjo ir sustingo greta pavirtusios taurès. Savo suformuotais klausimais apie ši objektą iš respondentų menininke norejjo išgauti atsakyma, kaip žmonès supranta unikalaus kūrinio apibrèžti, kaip suvokia jo ribas. Ar demonstruojamas pramoninis, bet menininko paveiktas daiktas jau gali būti vertinamas kaip meno kūrinys? İtaigiai tiriamojo objekto specifiką apibūdino vitražininkas Žydrūnas Mirinavičius: „I. Stulgaitè savo kūrinyje naudoja ready made' $a$, tačiau jis nèra vienalytis. Nors tai masinès produkcijos stiklo taure, tačiau ji ištraukta iš bevardžiu, uniforminiu, utilitarią funkciją atliekančių taurių milijoninès armijos, jos pavidalas pakeistas gyvos, valingos rankos prisilietimu. Ji igavo savitą charakterį, ji skleidžia emocija, ją galime kontempliuoti, racionaliai aptarti (...). Keistai paveiki yra ši tauré. Joje sustingusi atomazga, mums už nugaros ivvykusios dramos padarinys, ị kuri mes žvelgiame post factum" (Mirinavičius 2017).

Žinoma, tyrimo respondentu atsakymai buvo gana įvairūs ir skirtingi, tačiau jie neabejotinai praplèté kūrinio suvokimo ribas, kvestionavo meno vertinimo kriterijus. Beje, šiais klausimais StulgaitèKriukienè domëjosi ne karta, pokalbiuose su menotyrininkais įnirtingai gynè savo kaip menininkès statusą ir priklausomybę ne tik savojo cecho (t. y. stiklininkų), bet ir tiesiog šiuolaikinio meno kūrejju, netgi tyreju grupei (Negąsdinkime vieni kitu. Pokalbis su stiklo menininke Indre Stulgaite-Kriukiene 2017: 46-50).

Pramoninès stiklo taurès kaip kūrybinio objekto epopejją užbaigè $2020 \mathrm{~m}$. autorès sukurta didžiulè instaliacija „Be pavadinimo". Čia i kvadrato formatą buvo sustatytos apverstos ir vèl dailininkès „paveiktos” taurès. Ypatingo jautraus virpesio ir optinio žaismo joms suteikè raudona lazerinè šviesa, i bendrą skaidrią stiklo masę illiejusi energijos, gyvybès ir intrigos.

Greta kūriniu su tauriu specifika derètų paminèti ir kiek kitokių vizualiu sprendimu darbus, kuriuos pastarajij dešimtmetį menininkè sukūrè kartu su savo vyru R. Kriuku. Šie konceptualūs darbai buvo eksponuoti tiek Lietuvoje, tiek įvairiose užsienio šalyse. Ukrainos stiklo meno tyrejjas Mykhailo Bokotei teigè: „projektas, kuris paliko žymę miesto meno istorijoje, buvo lietuvių sutuoktinių Remigijaus Kriuko ir Indrès Stulgaitès paroda Lvovo stiklo muziejuje 2013 metais. Ukrainos stiklo menininkams didžiulị ịspūdi padarè visiškai kitokia per- 
formanso technika, tipiškas „Baltijos mokyklai" dekoras, formos, ititikinantys dekoratyviniai efektai ir didelis demesys medžiagos kokybei"9 (Bokotei 2020).

Iš tokių bendru šios menininkų poros kūrybos pavyzdžiu būtu galima paminèti instaliaciją „Pelkè“ (2017), kur siekiant idejos išraiškos ir įtaigumo prireikè įvairių medžiaginių medijų dermès ${ }^{10}$. „Pelkès“ eksponavimui buvo naudojama sudètinga metalinè konstrukcija, iš kurios išlindę tamsoje švytintys stiklo „stagarai" neabejotinai glumino ir traukè žiūrovų dèmesį. Bendras kūrinio vaizdas imponavo slèpiningumu, keistumu. Tais pačiais $2017 \mathrm{~m}$. buvo sukurtas turbūt žinomiausias Kriukų poros instaliacija

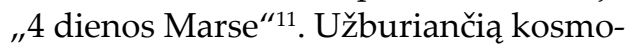
so aplinką teigiančioje ir nerealios erdvès ispūdi keliančioje uždaroje patalpoje žiūrovai vaikščiojo apgaubti dūmų, keistú garsų, o tamsoje, apsipratus akims, išvysdavo amorfiškas, „nežemiškas" stiklo skulptūras. Šiame sudètingame projekte veikẻ įvairūs žmogaus fiziniu pojūčuu receptoriai, žiūrovus akivaizdžiai intrigavo ìvairių meniniu priemoniu sintezè, o tiesioginis žiūrovo dalyvavimas kūrinyje taip pat sudarè jo pridètinę vertę (Stulgaitė Kriukienė 2020: 94).

\section{APIBENDRINIMAS}

$X X$ a. pradžioje Lietuvoje vyraujanti stiklo dailininkų kūrybinè tendencija buvo abstraktus ir figūratyvus skulptūrinis stiklas. Stulgaitės-Kriukienės ankstyvojo kūrybinio tarpsnio darbus taip pat galime priskirti prie šios tendencijos. Šio periodo jos kūriniu tematika, plastiniai sprendimai, kūrinio visumos paieškos atskleide tai, kad dailininkei imponavo tiek kūrinio naratyvas (žmogaus egzistencinès, moralinès bei dvasinès vertybès), tiek stiklo kaip medžiagos estetika, kuriu perteikimui buvo pasitelkiama sudètinga, technologiju ivvaldymu pagrista skulptūrinè stiklo forma. Daugelyje dailininkès kūriniu tuo metu vyravo karšto stiklo apdirbimo technika, stipriai talkinusi igyvendinant menininkès idèjas. Vis dèlto jau šiuo laikotarpiu galèjome išvysti autorès sieki eksperimentuoti, pamažu praplèsti skulptūriškumo ribas postmoderniomis išraiškos priemonemis (ready made'ais, instaliacijomis ir pan.).

Brandžiuoju kūrybos tarpsniu Stulgaitės-Kriukienès meniniai ieškojimai dar labiau pakrypo konceptualumo linkme. Atlikti įvairūs bandymai bei tyrimai, darbuose panaudoti deriniai su pramoninès gamybos elementais, kitomis, nestikliškomis medžiagomis ar netgi ne dailès srities medijomis, sudètingi kūrinių formatai atskleidè, kad šiandien stiklo menininkas turi daugybę galimybiu savo gebėjimus panaudoti avangardiniame kūrybos lauke. O stiklo, kaip buvusio dizaino, taikomojo meno objekto, ribos yra itin nutolusios nuo dar prieš porą dešimtmečiu gyvavusio dailès rūšių kategorizavimo.

Vis dèlto darbas stiklo studijoje Stulgaitei-Kriukienei ir toliau yra reikšmingas kaip puiki techninè bazė siekiant igyvendinti tiek dizaineriškus ar skulptūrinius, tiek ir sudètingus konceptualius šiuolaikinio meno kūrinius, o jos technologiniai igūdžiai tapo nepaprasto meistriškumo ir virtuoziškumo garantas rengiant ivvairialypius eksperimentavimus, personalines ekspozicijas ir unikalias autorines parodas. 


\section{Literatūra}

Aksamitauskaitė Goda. 2017. Skysto smèlio viražai, Literatūra ir menas 10 27: 25.

Bokotei Mykhailo. 2020. International Blown Glass Symposiums in Lviv: Influence Level in Ukrainian Decorative Art on the Edge of Centuries, International Journal of Psychosocial Rehabilitation 24 (8). DOI: 10.37200/IJPR/V24I8/PR281115. Pasiekiamas: https://www.psychosocial.com/ article/PR281115/26529/ [žr. 202106 09]

European Glass Context 2008: Exhibition Catalogue. Published by Bornholms Kunstmuseum, Denmark.

Kogelytė-Simanaitienè Raimonda. 2009. Jaunieji VDA talentai. Stiklo meno studijos Kaune. Talentas büti reikalingam: 68-69. Vilnius: Vilniaus dailès akademijos leidykla.

Kogelytė-Simanaitienė Raimonda. 2014. Kūrybą ir gyvenimą susieję su stiklu... (apie stiklininkus

\section{Nuorodos}

1 Interviu su dailininke. Kaunas, 2021 m. birželio $10 \mathrm{~d}$.

2 Šiam darbui vadovavo stiklo menininkas doc. Vytautas Janulionis.

3 Gerokai vẻliau dailininkei pavyko aplankyti šio stiklo menininko studiją Švedijoje.

4 Vis dèlto menotyrininkų straipsnių apie dailininkès kūrybą turime vos keletą. Tai taip pat skatina tyrinèti jos meninius laimèjimus.

5 Šis darbas buvo sukurtas kaip baigiamasis magistro projektas (vadovas prof. Valmantas Gutauskas).

6 Šia tema studijuodama VDA meno aspirantūroje menininkè rašè meno licenciato mokslinį referatą (vadovè dr. Raimonda Simanaitienè).

7 Studijinis stiklo judejimas prasidèjo JAV XX a. 7 deš., kai dailininkai ne fabrike, o privačiose dirbtuvèse èmèsi gaminti autorinius meno kūrinius. Vèliau, XX a. 8 deš., šis judejjimas paplito ir Europoje.

8 „Brizas“ buvo eksponuotas daugelyje parodų, bet viena svarbiausiu galime laikyti $2017 \mathrm{~m}$. Vilniuje, Taikomosios dailès ir dizaino muziejuje surengtą I. Stulgaitès-Kriukienès ir R. Kriuko autorinę parodą „Monologai“.
Remigijų Kriuką ir Indrę Stulgaitę-Kriukienę), Daile 64 (2): 95-105.

Mirinavičius Žydrūnas. 2017. Post factum. Rankraštis. Vilnius.

Negąsdinkime vieni kitų. Pokalbis su stiklo menininke Indre Stulgaite-Kriukiene. 2017. Kultūros barai 10: 46-50. Pasiekiamas: http://www.kulturosbarai.1t/uploads/news/id120/KB_2017_10_ WEB.pdf [žr. 202106 09]

Simanaitienè Raimonda. 2017. A Century of Professional Lithuanian Glass Art. Berlin: Scholars' Press.

Stulgaité-Kriukienė Indrè. 2020. Studijinio stiklo judejimo transformacijos: nuo funkcionalaus iki konceptualaus meno kūrinio. Vilnius: VDA leidykla.

Šatavičiūtè-Natalevičienè Lijana. 2018. Atkurtos Lietuvos šimtmečio žingsniai ataidi taikomojoje daileje ir dizaine. Taikomoji daile ir dizainas 19182018: 11-57. Vilnius: Lietuvos dailès muziejus.

9 Beje, šio menotyrininko tẻvas, ukrainietis dailininkas Andrei Bokotei yra vienas žymiausių $X X$ a. II pusès-XXI a. pradžios pasaulinio lygio stiklo menininkų. O Lvovas jau nuo sovietmečio garsejjo kaip išskirtinė eksperimentinė stiklo bazè. Tuo laikotarpiu kurti ne gamyklini, o autorinị stiklą čia važiuodavo stiklininkai iš visų Sovietų Sąjungos kampelių. Šias stiklo bazès tradicijas miestui pavyko išsaugoti iki dabarties: nūdien Lvove rengiami tarptautiniai stiklo meno simpoziumai, žinomi daugelyje užsienio šalių.

10 "Pelkèje“ pasinaudota stiklo, metalo, šviesos ir garso sinteze.

11 "Marso" kūrinyje stiklo skulptūrų autorius buvo R. Kriukas, o instaliacijos idejos, ekspozicijos dizaino, šviesos, garso, dūmų poveikio sumanytoja - I. Stulgaitè-Kriukienè. Instaliacija skirta ir pirmą kartą demonstruota šiuolaikinio meno mugèje „ArtVilnius” (Litexpo rūmuose) 2017 m. birželi. Menininkai R. Kriukas ir I. Stulgaitė-Kriukienè tais metais gavo žiūrovu prizą kartu su juos pristačiusia „Dusetų dailès galerija“. Vèliau šis darbas buvo pakartotas ir kitose ekspozicijose. 